\title{
SPOŁECZEŃSTWO INFORMACYJNE - POJĘCIE, POMIAR I STOPIEŃ ROZWOJU W POLSCE
}

\section{Wstęp}

Druga połowa XX w., a zwłaszcza początek obecnego stulecia, to okres znaczących przemian na świecie związanych $\mathrm{z}$ rozwojem technologii informacyjno-komunikacyjnych i kształtowaniem się społeczeństwa informacyjnego. Powstawanie tego społeczeństwa jest jednak procesem złożonym, obejmującym różne dziedziny życia społeczno-gospodarczego. Konieczne staje się więc tworzenie warunków sprzyjających kształtowaniu się społeczeństwa informacyjnego w poszczególnych krajach, jak również systematyczna ocena poziomu rozwoju tego społeczeństwa, umożliwiająca jednocześnie identyfikację barier występujących w tym zakresie.

W artykule dokonano identyfikacji pojęcia „społeczeństwo informacyjne” i jego cech charakterystycznych oraz wskazano niezwykle istotny i wciąż aktualny problem pomiaru tego społeczeństwa oraz wybrane, stosowane w tym celu mierniki. Następnie dokonano oceny pozycji Polski pod względem rozwoju społeczeństwa informacyjnego w skali Europy i świata oraz zmian, jakie nastąpiły w tym zakresie w ostatnich latach.

\section{Społeczeństwo informacyjne - definicja pojęcia i cechy charakterystyczne}

Termin „społeczeństwo informacyjne” (information society) powstał w drugiej połowie XX w. Mimo to nawet dziś trudno precyzyjnie określić czym naprawdę jest społeczeństwo informacyjne i jakimi cechami, zwłaszcza mierzalnymi, się ono odznacza. Choć do tej pory powstało wiele prac poświęconych problematyce „nowego" społeczeństwa, nawet pobieżna analiza literatury przedmiotu pozwala stwierdzić wielość oraz znaczną różnorodność definicji społeczeństwa informacyjnego ${ }^{1}$. Wśród nich można bowiem wymienić definicje

* Doktorantka, Katedra Gospodarki Regionalnej i Środowiska, Wydział Ekonomiczno-Socjologiczny UŁ.

${ }^{1}$ Zob. np.: J.S. Nowak, Spoleczeństwo informacyjne - geneza i definicje, [w:] P. Sienkiewicz, J.S. Nowak (red.), Społeczeństwo informacyjne. Krok naprzód, dwa kroki wstecz, Polskie Towarzystwo Informatyczne - Oddział Górnośląski, Katowice, 2008, s. 25-36. 
bardzo ogólne (jako przykład można wskazać definicję proponowaną przez J. Mączyńskiego, zgodnie z którą społeczeństwo informacyjne to takie, które informacje wytwarza, przechowuje, przekazuje, pobiera i wykorzystuje ${ }^{2}$ ), jak i bardziej szczegółowe (na przykład T. Goban-Klas i P. Sienkiewicz definiują społeczeństwo informacyjne jako ,społeczeństwo, które nie tylko posiada rozwinięte środki przetwarzania informacji i komunikowania, lecz przetwarzanie informacji jest podstawą tworzenia dochodu narodowego i dostarcza źródła utrzymania większości społeczeństwa"”3), a także definicje prezentujące szerokie rozumienie społeczeństwa informacyjnego. Do ostatniej grupy można zaliczyć na przykład definicję pochodzącą ze Strategii rozwoju spoteczeństwa informacyjnego w Polsce do roku 2013. W dokumencie tym wskazano, że jest to ,społeczeństwo, w którym przetwarzanie informacji z wykorzystaniem technologii informacyjnych i komunikacyjnych stanowi znaczącą wartość ekonomiczną, społeczną i kulturową"4. Definicja ta odwołuje się zatem do różnych sfer życia, zwracając tym samym uwagę na różne aspekty społeczeństwa informacyjnego.

Powyższe definicje oczywiście nie wyczerpują całego zbioru definicji społeczeństwa informacyjnego i stanowią jedynie niewielki jego wycinek. Mimo to, już na ich przykładzie wyraźnie widać, że społeczeństwo informacyjne jest różnie rozumiane. Co więcej, poszczególne definicje nie precyzują dokładnie, czym jest społeczeństwo informacyjne, a bardziej przedstawiają jego charakterystykę. Stanowią one bowiem często zbiór cech, którymi się ono odznacza.

Oczywiście w zależności od przyjętej definicji można wskazać różne cechy społeczeństwa informacyjnego. Mimo to, przynajmniej w pewnym stopniu, możliwa jest identyfikacja zbioru cech najbardziej dla niego charakterystycznych. Wśród elementarnych cech społeczeństwa informacyjnego można wymienić na przykład: wytwarzanie, przechowywanie, przekazywanie oraz pobieranie i wykorzystywanie informacji ${ }^{5}$. Bardziej szczegółowe spojrzenie na tę kwestię, zwłaszcza z punktu widzenia różnych dziedzin życia, proponuje N. Moore. Wyróżnił on bowiem trzy główne cechy społeczeństw informacyjnych, a mianowicie ${ }^{6}$ :

${ }^{2}$ J. Mączyński, Globalne społeczeństwo informacyjne. Wybrane kwestie adaptacyjne, [w:] L.W. Zacher (red.), Rewolucja informacyjna i społeczeństwo. Niektóre trendy, zjawiska i kontrowersje, Fundacja Edukacyjna „Transformacje”, Warszawa, 1997, za: Społeczeństwo informacyjne w Polsce. Wyniki badań statystycznych z lat 2004-2008, GUS, Warszawa 2010, s. 7.

${ }^{3}$ T. Goban-Klas, P. Sienkiewicz, Społeczeństwo informacyjne: szanse, zagrożenia, wyzwania, Wyd. Fundacji Postępu Telekomunikacji, Kraków, 1999, s. 43.

${ }^{4}$ Strategia rozwoju spoleczeństwa informacyjnego w Polsce do roku 2013, Ministerstwo Spraw Wewnętrznych i Administracji, Warszawa 2008, s. 2.

${ }^{5}$ M. Konopka, Istota i rozwój spoleczeństwa informacyjnego, [w:] M. Witkowska, K. Cholawo-Sosnowska (red.), Społeczeństwo inform@cyjne. Istota, rozwój, wyzwania, Wyd. Akademickie i Profesjonalne, Warszawa, 2006, s. 19-21.

${ }^{6}$ N. Moore, The information society, World Information Report 1997/1998, UNESCO, Paris 1997, s. 271-272. 
- dla społeczeństwa informacyjnego charakterystyczne jest wykorzystanie informacji jako zasobu ekonomicznego,

- w społeczeństwach informacyjnych można dostrzec większe wykorzystanie informacji wśród ogółu społeczeństwa,

- społeczeństwa te charakteryzują się rozwojem w gospodarce tzw. sektora informacyjnego.

Ograniczone ramy niniejszego opracowania umożliwiają przedstawienie jedynie wybranych definicji społeczeństwa informacyjnego i jego cech charakterystycznych. Jednakże są to zagadnienia kluczowe, zwłaszcza w zakresie pomiaru społeczeństwa informacyjnego, który wciąż stanowi istotne wyzwanie badawcze.

\section{Pomiar stopnia rozwoju społeczeństwa informacyjnego i obecnie stosowane mierniki}

Społeczeństwo informacyjne nie jest terminem funkcjonującym jedynie $\mathrm{w}$ teorii, ale również w polityce państw i instytucji międzynarodowych. Koniec ubiegłego stulecia to na przykład początki idei tworzenia społeczeństwa informacyjnego w Unii Europejskiej, a w kolejnych latach także i w Polsce. W konsekwencji rodzi się coraz większa potrzeba pomiaru stopnia rozwoju tego społeczeństwa. Pomiar ten napotyka jednak szereg problemów i różne czynniki utrudniają badania w tym zakresie.

W przypadku pomiaru poziomu rozwoju społeczeństwa informacyjnego kluczowe znaczenie mają oczywiście kwestie definicyjne. Wielość i różnorodność definicji tego terminu z pewnością nie ułatwiają tego zadania. Co więcej, jak słusznie podkreśla J.S. Nowak, większość definicji społeczeństwa informacyjnego jest mało konkretna ${ }^{7}$. Niekiedy odznaczają się one bowiem nawet znacznym poziomem ogólności, a poza tym z reguły nie określają jak wymiernie identyfikować dane społeczeństwo jako informacyjne (jak np. przytoczone wcześniej definicje), co dodatkowo utrudnia prowadzenie badań w tym zakresie. Nie są to jednak jedyne czynniki, które ograniczają pomiar poziomu rozwoju społeczeństwa informacyjnego na danym obszarze. Istotne są również dwie inne kwestie, a mianowicie: dostępność danych statystycznych możliwych do wykorzystania, a nawet wiarygodność branych pod uwagę wskaźników. Jak wskazuje bowiem R. Kupczyk, dynamiczne współcześnie tempo przemian technologicznych rodzi konieczność aktualizacji i monitorowania wskaźników, a nawet konstruowania ich w sposób doraźny, dla pomiaru konkretnych celów ${ }^{8}$.

\footnotetext{
${ }^{7}$ J.S. Nowak, Spoleczeństwo informacyjne-geneza..., s. 34.

${ }^{8}$ R. Kupczyk, Gospodarczo-polityczne uwarunkowania rozwoju społeczeństwa informacyjnego, Wyd. Akademii Polonijnej „Educator”, Częstochowa, 2006, s. 34.
} 
Wraz z rozwojem technologii informacyjno-komunikacyjnych i nowych możliwości ich zastosowania $\mathrm{z}$ biegiem czasu zmienia się zatem rola wykorzystywanych wskaźników. Z punktu widzenia oceny zaawansowania przekształceń w kierunku społeczeństwa informacyjnego coraz większego znaczenia zaczyna bowiem nabierać na przykład rodzaj i jakość posiadanego łącza z Internetem, czy odsetek jego użytkowników niż dostęp do komputerów i Internetu, który staje się po prostu coraz bardziej powszechny.

Wskazane trudności, jakie napotyka się podczas pomiaru stopnia rozwoju społeczeństwa informacyjnego, nie są oczywiście jedyne. Mimo to, z pewnością można je zaliczyć do jednych z najważniejszych ${ }^{9}$.

Jak można zatem mierzyć poziom rozwoju społeczeństwa informacyjnego? W zasobach statystyki publicznej funkcjonują różne przydatne dane mające charakter ,prostych” wskaźników. Wieloaspektowość społeczeństwa informacyjnego rodzi jednak potrzebę bardziej ogólnego i syntetycznego spojrzenia na związane z nim zjawiska i procesy, wskutek czego pomiar stopnia rozwoju społeczeństwa informacyjnego coraz częściej dokonywany jest przy pomocy różnych miar zagregowanych. Stosowanie takich metod pomiaru staje się wręcz nieuniknione. Wskaźniki proste odnoszą się bowiem tylko do pojedynczego, łatwo definiowalnego aspektu tego społeczeństwa (np. technologicznego), natomiast dopiero mierniki zagregowane pozwalają uwzględnić większą ich liczbę $^{10}$.

Do oceny stopnia rozwoju społeczeństwa informacyjnego, czy technologii informacyjno-komunikacyjnych $\mathrm{w}$ skali międzynarodowej tworzono różne miary zagregowane ${ }^{11}$, jednak tylko niektóre $\mathrm{z}$ nich wciąż są przedmiotem badań i analiz w zakresie rozwoju społeczeństwa informacyjnego na świecie. Co więcej, nie zawsze funkcjonują one w niezmienionej formie. Wśród aktualnie stosowanych mierników warto wymienić dwa indeksy syntetyczne: ICT Development Index oraz Networked Readiness Index.

9 Problem pomiaru społeczeństwa informacyjnego szeroko omawia w swojej pracy M. Goliński, wskazując przy tym różne czynniki utrudniające statystyczne monitorowanie problematyki tego społeczeństwa. Szerzej: M. Goliński, Społeczeństwo informacyjne - geneza koncepcji i problematyka pomiaru, Wyd. SGH, Warszawa, 2011, s. 141-163.

${ }^{10}$ Wskaźnikom prostym w zakresie pomiaru stopnia rozwoju społeczeństwa informacyjnego poświęcona jest praca M. Luterka. Szerzej: M. Luterek, Mierzalność społeczeństwa informacyjnego za pomoca wskaźników prostych; http://www.bbc.uw.edu.pl/Content/20/10.pdf (dostęp 17.06.2013.

${ }^{11}$ Omówienie kilkunastu indeksów złożonych społeczeństwa informacyjnego zawiera praca M. Golińskiego. Niektóre $\mathrm{z}$ indeksów syntetycznych przedstawiono również w innych opracowaniach. Zob. m.in.: M. Goliński, Społeczeństwo informacyjne - geneza koncepcji..., s. 165-215; M. Luterek, E-government. Systemy informacji publicznej, Wyd. Akademickie i Profesjonalne, Warszawa, 2010, s. 17-27 oraz Projekt ESPON 1.2.3 Identyfikacja istotnych przestrzennie aspektów społeczeństwa informacyjnego, Raport końcowy 2007. 
ICT Development Index został skonstruowany przez międzynarodową organizację International Telecommunication Union (ITU) w roku 2008 i opublikowany rok później. W najnowszym raporcie ITU (Measuring the Information Society 2012) wartości ICT Development Index obliczono dla 155 krajów $\mathrm{z}$ całego świata. Indeks ten wciąż bazuje na jedenastu prostych wskaźnikach zebranych $\mathrm{w}$ trzy mierniki cząstkowe o zróżnicowanych wagach: „dostęp do ICT” (waga 0,4$)$, „wykorzystanie ICT” $(0,4)$ oraz „umiejętności $(0,2) .{ }^{12}$ Biorąc pod uwagę jego strukturę, uwzględnia on zarówno kwestie technologiczne rozwoju społeczeństwa informacyjnego (infrastruktura ICT i dostęp do niej), jak i wykorzystanie technologii informacyjno-komunikacyjnych. Co więcej, odrębną część miernika stanowią wskaźniki dotyczące umiejętności. ICT Development Index uwzględnia więc także aspekt społeczeństwa informacyjnego związany z edukacją i wykształceniem ludności.

Kolejnym wskaźnikiem wciąż stosowanym w analizach międzynarodowych w zakresie rozwoju społeczeństwa informacyjnego i technologii ICT jest indeks gotowości sieciowej (Networked Readiness Index - NRI), publikowany co roku w raporcie The Global Information Technology Report przez World Economic Forum. Warto dokładniej przedstawić obecną strukturę tego indeksu (w istniejącej literaturze pojawia się bowiem w większości jej forma dotychczasowa), gdyż od momentu jego powstania uległa ona zmianie. W tym momencie (zgodnie $\mathrm{z}$ najnowszym dwunastym raportem The Global Information Technology Report 2013) indeks NRI stanowi średnią arytmetyczną czterech głównych mierników cząstkowych (otoczenie, gotowość, wykorzystanie i oddziaływanie), które składają się z 10 filarów reprezentujących mierniki cząstkowe niższego poziomu (tabela 1). W najnowszym badaniu NRI był wyliczany według 54 zmiennych dla 144 krajów świata ${ }^{13}$.

Tabela 1. Struktura Networked Readiness Index (mierniki cząstkowe)

\begin{tabular}{|l|l|l|l|}
\hline \multicolumn{4}{|c|}{ Networked Readiness Index } \\
\hline \multicolumn{1}{|c|}{ Otoczenie } & \multicolumn{1}{|c|}{ Gotowość } & \multicolumn{1}{c|}{ Wykorzystanie } & \multicolumn{1}{|c|}{ Oddziaływanie } \\
\hline Otoczenie polityczne & Infrastruktura & Wykorzystanie na poziomie & Skutki ekono- \\
i prawne & i treści cyfrowe & indywidualnym & miczne \\
Otoczenie dla biznesu & Koszty & Wykorzystanie przez przed- & Skutki społeczne \\
i innowacji & Umiejętności & siębiorstwa & \\
& & Wykorzystanie na poziomie & \\
& & administracji publicznej & \\
\hline
\end{tabular}

Źródło: opracowanie na podstawie The Global Information Technology Report 2013 Growth and Jobs in a Hyperconnected World, World Economic Forum and INSEAD, Geneva 2013, s. 6-7.

${ }^{12}$ Zob.: International Telecommunication Union, http://www.itu.int oraz Measuring the Information Society 2012, International Telecommunication Union, Geneva 2012, s. 15-19.

${ }^{13}$ The Global Information Technology Report 2013. Growth and Jobs in a Hyperconnected World, World Economic Forum and INSEAD, Geneva, 2013, s. V, XI, 3-7; http://www.weforum.org/. 
W przypadku indeksu gotowości sieciowej kwestie takie, jak dostęp do technologii informacyjno-komunikacyjnych oraz „umiejętności” umieszczone zostały wspólnie (w ramach miernika cząstkowego ,gotowość"), podczas gdy w ICT Development Index zostały one rozdzielone. Wskaźnik NRI uwzględnia poza tym kwestie związane z szeroko rozumianym „otoczeniem” oraz po ostatnich zmianach zawiera w swojej strukturze nowy element - uwzględniono w nim skutki ekonomiczne i społeczne związane z rozwojem ICT jako czwarty miernik cząstkowy.

Tabela 2. Struktura Indeksu Społeczeństwa Informacyjnego ESPON

\begin{tabular}{|c|c|c|c|}
\hline \multirow{7}{*}{$\begin{array}{l}\text { Indeks SI } \\
\text { ESPON }\end{array}$} & \multirow{3}{*}{$\begin{array}{l}\text { Gotowość do SI } \\
\text { (zasoby i umiejętno- } \\
\text { ści dla korzystania z } \\
\text { ICT) }\end{array}$} & Bogactwo & $\begin{array}{l}\text { Dochód rozporządzalny gospo- } \\
\text { darstw domowych }\end{array}$ \\
\hline & & $\begin{array}{l}\text { Umiejętności/ } \\
\text { wykształcenie }\end{array}$ & $\begin{array}{l}\text { Zasoby ludzkie w nauce i techno- } \\
\text { logii }\end{array}$ \\
\hline & & $\begin{array}{l}\text { Przyswajanie } \\
\text { podstawowych } \\
\text { technologii }\end{array}$ & $\begin{array}{l}\text { Gospodarstwa domowe ze } \\
\text { stacjonarną linią telefoniczną }\end{array}$ \\
\hline & \multirow[t]{2}{*}{$\begin{array}{l}\text { Wzrost SI (dostęp- } \\
\text { ność i wykorzystanie } \\
\text { ICT) }\end{array}$} & $\begin{array}{l}\text { Gospodarstwa } \\
\text { domowe }\end{array}$ & $\begin{array}{l}\text { Gospodarstwa domowe z kompute- } \\
\text { rem osobistym, } \\
\text { Gospodarstwa domowe z przy- } \\
\text { najmniej jednym telefonem } \\
\text { komórkowym, } \\
\text { Gospodarstwa domowe z dostępem } \\
\text { do Internetu, } \\
\text { Gospodarstwa domowe z szeroko- } \\
\text { pasmowym dostępem do Internetu }\end{array}$ \\
\hline & & Firmy & $\begin{array}{l}\text { Dostęp do sieci światłowodowej, } \\
\text { Firmy z dostępem do Internetu, } \\
\text { Firmy mające własną stronę } \\
\text { internetową }\end{array}$ \\
\hline & \multirow{2}{*}{$\begin{array}{l}\text { Oddziaływanie SI } \\
\text { (konsekwencje } \\
\text { gospodarcze SI) }\end{array}$} & $\begin{array}{l}\text { Oddziaływanie } \\
\text { na rynek pracy }\end{array}$ & Zatrudnienie w sektorze high-tech \\
\hline & & $\begin{array}{l}\text { Działalność } \\
\text { innowacyjna }\end{array}$ & Patenty w zakresie ICT \\
\hline
\end{tabular}

Źródło: opracowanie własne na podstawie: Projekt ESPON 1.2.3. Identyfikacja istotnych przestrzennie aspektów spoteczeństwa informacyjnego, Raport końcowy 2007, s. 106-107.

W literaturze można odnaleźć także mierniki tworzone w celu pomiaru stopnia rozwoju społeczeństwa informacyjnego w skali innej niż międzynaro- 
dowa. Szczególnie warto tutaj przedstawić indeks społeczeństwa informacyjnego skonstruowany w ramach Projektu ESPON 1.2.3. Identyfikacja istotnych przestrzennie aspektów społeczeństwa informacyjnego $\mathrm{w}$ celu pomiaru poziomu rozwoju tego społeczeństwa na poziomie regionalnym (regiony NUTS-2) wśród 29 krajów europejskich. Ten terytorialny indeks społeczeństwa informacyjnego składa się z trzech głównych mierników cząstkowych (,gotowość do SI ${ }^{14,}$, „wzrost SI” oraz „oddziaływanie SI”). Struktura tego indeksu nawiązuje bowiem do koncepcji cyklu życia społeczeństwa informacyjnego, a jego główne mierniki cząstkowe odpowiadają poszczególnym jego fazom (gotowości, intensywności i oddziaływania). Każdy $\mathrm{z}$ tych mierników ma przy tym jednakowy udział w ogólnym indeksie społeczeństwa informacyjnego (1/3) i dzieli się na mniejsze grupy wskaźników ${ }^{15}$. Strukturę indeksu ESPON przedstawia tabela 2.

Indeks społeczeństwa informacyjnego stworzony $\mathrm{w}$ ramach projektu ESPON uwzględnia zatem różne aspekty tego społeczeństwa charakteryzowane za pomocą dwunastu prostych wskaźników. Jak w przypadku większości tego rodzaju mierników uwzględniono tutaj dostęp i wykorzystanie technologii informacyjno-komunikacyjnych. Podobnie jak w przypadku ICT Development Index, czy Networked Readiness Index w Indeksie ESPON pojawiają się również kwestie związane z umiejętnościami i wykształceniem. Co więcej, nie pomija on kwestii ekonomicznych, uwzględniając nawet konsekwencje gospodarcze rozwoju społeczeństwa informacyjnego.

W kontekście pomiaru stopnia rozwoju społeczeństwa informacyjnego warto wspomnieć również o stworzonym przez Stowarzyszenie „Miasta w Internecie" wskaźniku tzw. potencjału e-rozwoju. Wskaźnik ten powstał w celu analiz rozwoju społeczeństwa informacyjnego na poziomie jednostek samorządu lokalnego (powiatów) i obejmuje trzy wskaźniki cząstkowe o zróżnicowanych wagach: gospodarczy, innowacyjny i edukacyjny. Szczegółową strukturę wskaźnika można odnaleźć m.in. w Strategii e-rozwoju województwa mazowieckiego na lata 2007-2013. Na potrzeby dokumentu zbadano potencjał e-rozwoju w województwie mazowieckim, a w ramach wskaźnika wzięto pod uwagę następujące zmienne: ${ }^{16}$

1. Wskaźnik innowacyjności (waga 0,4$)$ :

- odsetek bankomatów na 10 tys. mieszkańców,

- odsetek jednostek samorządu terytorialnego posiadających stronę www,

- liczba firm sektora ICT na 10 tys. mieszkańców;

${ }^{14} \mathrm{SI}=$ społeczeństwo informacyjne.

${ }^{15}$ Projekt ESPON 1.2.3. Identyfikacja istotnych ..., s. 37-39, 95-107.

${ }^{16}$ Strategia e-rozwoju województwa mazowieckiego na lata 2007-2013, Tarnów-Warszawa 2005/2006, s. 48-50. 
2. Wskaźnik gospodarczy $(0,4)$ :

- dochody własne powiatów w przeliczeniu na 1 mieszkańca,

- liczba podmiotów zarejestrowanych w rejestrze REGON na 1000 mieszkańców,

- stopa bezrobocia;

3. Wskaźnik edukacyjny $(0,2)$ :

- liczba mieszkańców przypadających na jedną szkołę średnią.

Wskaźnik potencjału e-rozwoju w niewielkim stopniu przypomina miary społeczeństwa informacyjnego tworzone na potrzeby analiz międzynarodowych, $\mathrm{w}$ tym przedstawione $\mathrm{w}$ pracy trzy indeksy. Jest to jednak nieuniknione $\mathrm{z}$ uwagi na znacznie ograniczoną dostępność danych statystycznych w obszarze społeczeństwa informacyjnego w tak małej skali, jak poziom lokalny.

Analiza literatury przedmiotu pozwala dostrzec wiele różnych metod pomiaru stopnia rozwoju społeczeństwa informacyjnego. Co więcej, jak trafnie zauważa M. Luterek, w zależności od tego, jak postrzegane jest społeczeństwo informacyjne (jako zjawisko/proces o charakterze bardziej ekonomicznym, społecznym, czy technologicznym), przy pomiarze stopnia jego rozwoju stosuje się te wskaźniki, które w większym stopniu charakteryzują aspekt uznawany przez danego badacza za bardziej istotny ${ }^{17}$. Mimo to, badania prowadzone $\mathrm{w}$ tym zakresie powinny $\mathrm{w}$ miarę możliwości uwzględniać jak najszersze spojrzenie na problematykę społeczeństwa informacyjnego.

\section{Społeczeństwo informacyjne w Polsce na tle Europy i świata}

\subsection{Dostęp do Internetu}

Kluczowym elementem procesu powstawania społeczeństwa informacyjnego jest oczywiście dostęp do technologii informacyjno-komunikacyjnych, a przede wszystkim do Internetu. I choć w chwili obecnej wydaje się on już prawie powszechny, jeszcze kilka lat temu sytuacja w Polsce, jak i w innych krajach, wyglądała zupełnie inaczej. Rysunek 1 przedstawia poziom dostępu do Internetu wśród mieszkańców w Polsce i Unii Europejskiej w latach 2006-2011.

W Polsce w 2006 r. zaledwie 26\% osób miało dostęp do Internetu w domu. W przypadku krajów Unii Europejskiej było to średnio $41 \%$. Od tamtej pory widoczny jest stały wzrost poziomu dostępu do Internetu, który w przypadku Polski był ponad dwukrotny. W roku 2011 w Polsce dostęp do Internetu w domu miało $60 \%$ osób, jednak wciąż była to wartość niższa od średniej unijnej (67\%). W 2011 r. najlepiej wyglądała sytuacja w tym zakresie w Szwecji i w Holandii, gdzie odsetek ten wyniósł aż 90\%. Najsłabiej wypadają pod tym względem dwa

\footnotetext{
${ }^{17}$ M. Luterek, E-government...., s. 17.
} 
kraje, które przystąpiły do Unii Europejskiej w 2007 r., a mianowicie: Rumunia (36\%) i Bułgaria (44\%). Co więcej, słabszą od Polski pozycję miały oprócz nich jeszcze Portugalia i Cypr (po 50\%) oraz Grecja (45\%) i Włochy $(48 \%)^{18}$, jak widać Polska zajęła jedną z końcowych lokat w rankingu. Dostęp do Internetu w Polsce na poziomie ok. $60 \%$ okazuje się więc niewielki, a dystans dzielący Polskę od czołówki krajów UE jest naprawdę znaczny. W 2011 r. zróżnicowanie pomiędzy wszystkimi krajami Unii Europejskiej w zakresie dostępu do Internetu w domu było bowiem niemałe (współczynnik zmienności $V_{s}$ wyniósł ok. 23\%).

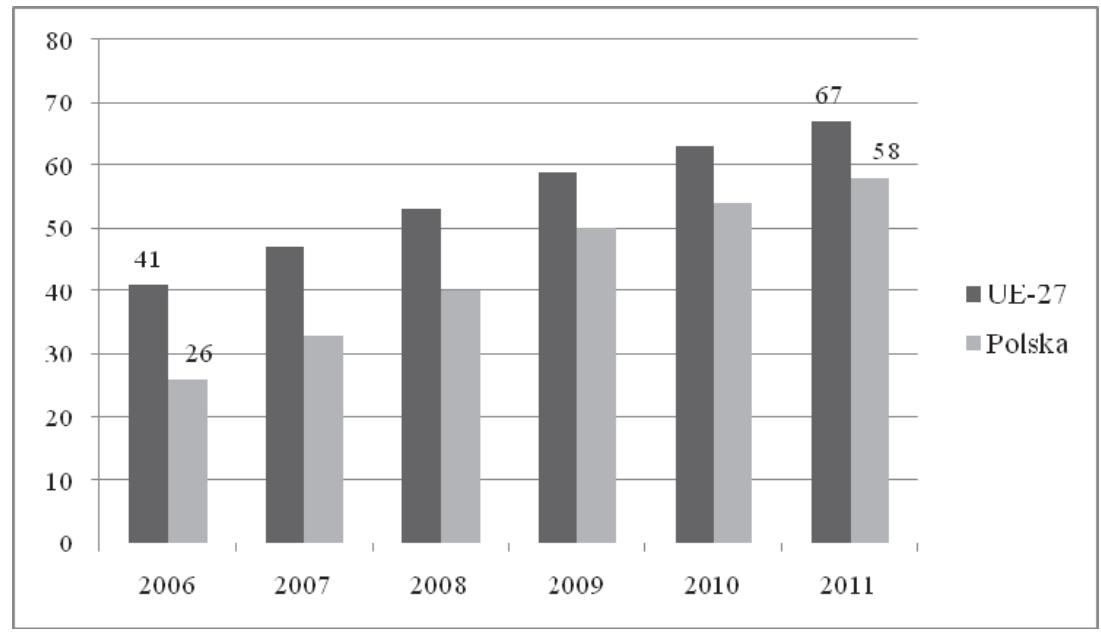

Rysunek 1. Osoby mające dostęp do Internetu w domu (w \%)

Źródło: opracowanie własne na podstawie danych Eurostatu (dotyczy rysunków 1-5).

Wskaźnikiem coraz bardziej nabierającym na znaczeniu w obszarze dostępu do technologii informacyjno-komunikacyjnych jest rodzaj posiadanego łącza z Internetem. Rysunek 2 przedstawia zatem sytuację gospodarstw domowych w Polsce i w Unii Europejskiej pod względem dostępu szerokopasmowego.

Biorąc pod uwagę rodzaj posiadanego łącza, w Polsce w 2007 roku 30\% gospodarstw domowych miało szerokopasmowe łącze z Internetem, podczas gdy w Unii Europejskiej było to 42\%. W roku 2012 odsetek ten był już znacznie wyższy $(67 \%)$, choć wciąż poniżej średniej unijnej (73\%). W porównaniu z poszczególnymi krajami Unii Polska wypada raczej słabo. Aż sześć państw osiągnęło wartość wskaźnika powyżej 80\% (wśród nich znalazły się Szwecja, Wielka Brytania, Finlandia, Holandia oraz Dania i Niemcy). Niższy niż w Polsce odsetek gospodarstw domowych z szerokopasmowym dostępem do Internetu miało dziewięć krajów, w tym najniższy był on w Rumunii (50\%) oraz

\footnotetext{
${ }^{18} \mathrm{http}: / /$ epp.eurostat.ec.europa.eu/portal/page/portal/information_society/data/database.
} 
w Grecji i Bułgarii (po 51\%). Poszczególne kraje Unii Europejskiej różnią się więc wyraźnie w zakresie szerokopasmowego dostępu gospodarstw domowych do Internetu (w 2012 roku $\left.V_{s}=16 \%\right)^{19}$, a Polska osiąga wartości wskaźnika niższe nie tylko od średniej unijnej, ale i od większości krajów członkowskich.

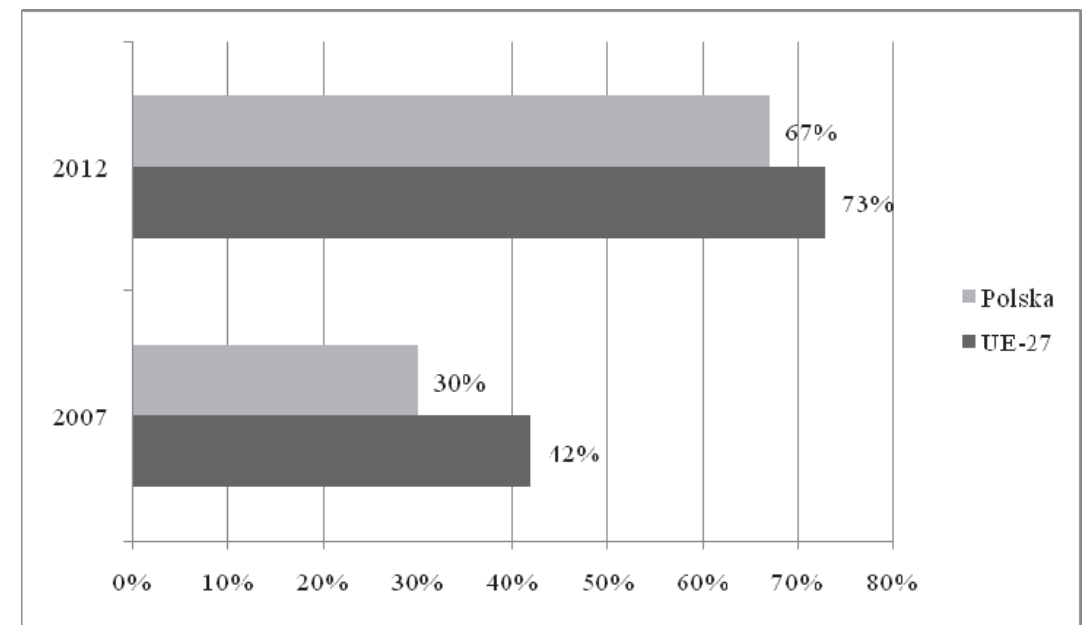

Rysunek 2. Gospodarstwa domowe mające szerokopasmowe łącze z Internetem w 2007 i 2012 r.

\subsection{Korzystanie z ICT oraz umiejętności}

Elementem większości mierników wykorzystywanych do pomiaru stopnia rozwoju społeczeństwa informacyjnego jest także korzystanie z ICT, zwłaszcza z Internetu. Jednym z podstawowych ,prostych” wskaźników wykorzystywanych do pomiaru poziomu tego wykorzystania jest odsetek użytkowników Internetu, w tym odsetek osób, które korzystają z niego codziennie.

Tabela 3. Odsetek osób codziennie korzystających z Internetu w Polsce i w Unii Europejskiej w latach 2006-2012

\begin{tabular}{|l|c|c|c|}
\hline \multirow{2}{*}{} & \multicolumn{3}{|c|}{ Lata } \\
\cline { 2 - 4 } & 2006 & 2009 & 2012 \\
\hline UE-27 & $31 \%$ & $48 \%$ & $59 \%$ \\
\hline Polska & $22 \%$ & $39 \%$ & $46 \%$ \\
\hline
\end{tabular}

Źródło: opracowanie własne na podstawie danych Eurostatu: http://epp.eurostat.ec.europa.eu/portal/page/portal/information_society/ data/database

\footnotetext{
${ }^{19}$ Ibidem.
} 
W Polsce w 2006 r. 22\% osób korzystało codziennie z Internetu, podczas gdy w Unii Europejskiej już co trzecia. Od tamtej pory sytuacja uległa znacznej poprawie - zarówno w Polsce, jak i w całej Unii Europejskiej odsetek ten zwiększył się ponad dwukrotnie. Należy jednak pamiętać, że wartości tego wskaźnika są uzależnione w znacznym stopniu od dostępu do Internetu, który to nie zawsze jest czynnikiem wystarczającym do korzystania z „,sieci”.

Istotnym elementem budowy społeczeństwa informacyjnego, związanym $\mathrm{z}$ korzystaniem $\mathrm{z}$ technologii informacyjno-komunikacyjnych, jest $\mathrm{w}$ coraz większym stopniu także rozwój e-administracji i e-usług publicznych. Ważnym wskaźnikiem w zakresie korzystania z ICT staje się więc tutaj korzystanie $\mathrm{z}$ Internetu w kontaktach $\mathrm{z}$ administracją publiczną.

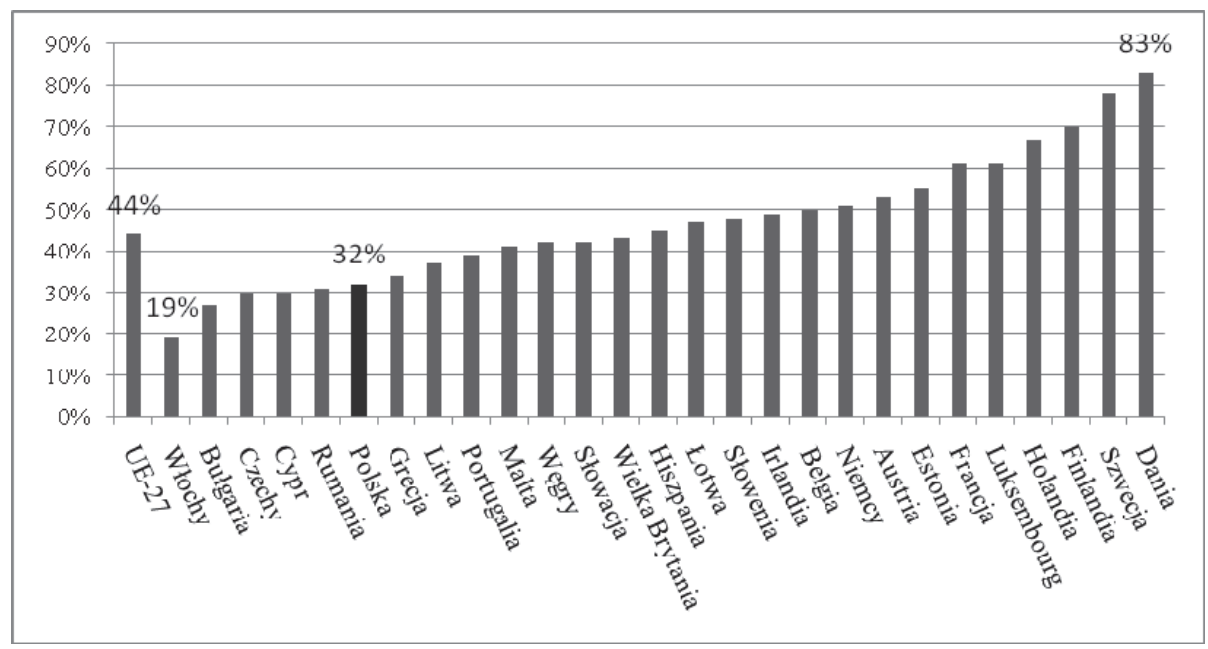

Rysunek 3. Odsetek osób korzystających z Internetu w kontaktach z administracją publiczną (w ciągu ostatnich 12 miesięcy) w 2012 roku

W Polsce w 2012 r. ponad 30\% mieszkańców wykorzystywało Internet w kontaktach z administracją publiczną. Średnia dla 27 krajów członkowskich Unii Europejskiej jest jednak wyższa i wyniosła dla tego roku 44\%. Najsłabiej pod tym względem wypadają Włochy (zaledwie 19\%), a najlepiej Szwecja $(78 \%)$ i Dania (83\%). Dla porównania w roku 2008 w Polsce było to $22 \%$ osób, podczas gdy średnia unijna wyniosła wtedy $36 \%$. W przypadku najnowszych danych Polska wypada zatem bardzo słabo pod względem wykorzystania Internetu w kontaktach $\mathrm{z}$ administracją publiczną.

Rozpatrując wykorzystanie ICT, zwłaszcza Internetu, warto także zwrócić uwagę na osoby, które nigdy wcześniej nie miały z nim do czynienia. Takie dane obrazują bowiem skalę wykluczenia cyfrowego w zakresie korzystania z ICT, jaka występuje w społeczeństwie. 


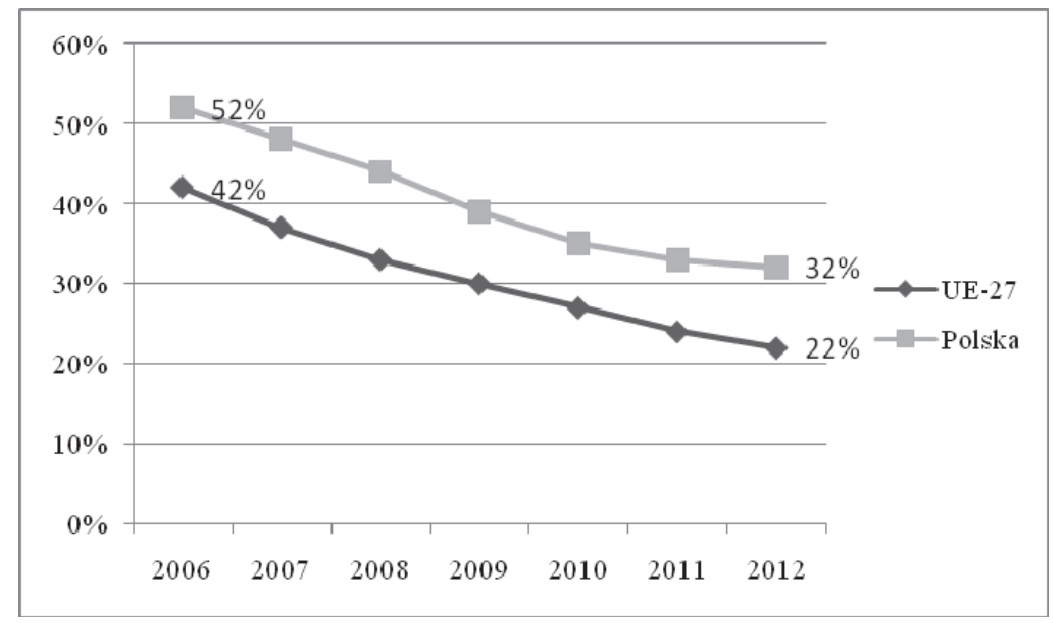

Rysunek 4. Odsetek osób, które nigdy nie korzystały z Internetu

W Polsce w 2006 r. ponad 50\% ogółu stanowiły osoby, które nigdy nie korzystały z Internetu, podczas gdy w 2012 r. już tylko co trzecia. Jednak jest to wciąż spory odsetek, który świadczy o wykluczeniu cyfrowym znacznej części społeczeństwa. W Unii Europejskiej w 2012 r. odsetek ten wyniósł średnio nieco ponad 20\%, choć w takich krajach, jak Szwecja, Finlandia, Holandia, Luksemburg i Dania było to zaledwie kilka procent (odpowiednio 5\%, 7\% i po $6 \% \mathrm{w}$ trzech ostatnich). Znacznie gorzej wyglądała natomiast sytuacja w Bułgarii (42\%) i Grecji (42\%), a zwłaszcza w Rumunii (48\%), gdzie odsetek takich osób był naprawdę znaczny ${ }^{20}$.

Elementem istotnym $\mathrm{z}$ punktu widzenia rozwoju społeczeństwa informacyjnego, warunkującym korzystanie $\mathrm{z}$ technologii informacyjno-komunikacyjnych, jest oczywiście posiadanie odpowiednich umiejętności. Jednym ze wskaźników dostępnych w bazie Eurostatu w tym zakresie jest odsetek gospodarstw domowych nieposiadających dostępu do Internetu $\mathrm{w}$ domu z uwagi na brak umiejętności.

Jak wynika z powyższego wykresu, w Polsce w 2012 roku 11\% gospodarstw domowych nie miało dostępu do Internetu w domu ze względu na brak odpowiednich w tym zakresie umiejętności. Średnia dla 26 krajów Unii Europejskiej była w tym przypadku nieco niższa i wyniosła $8 \%$. Warto jednak zauważyć, że w całej Unii znajdują się również kraje, w których wskaźnik ten był znacznie wyższy. Szczególnie wysokie jego wartości (na poziomie 25\%) dotyczyły bowiem w tym roku Portugalii oraz Grecji. 


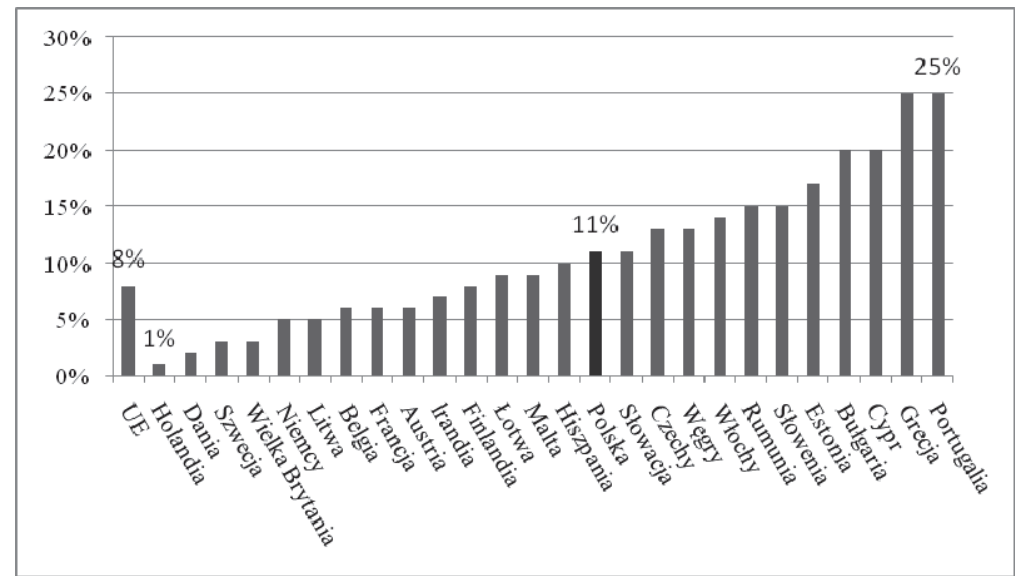

Rysunek 5. Odsetek gospodarstw domowych w 2012 r. bez dostępu do Internetu w domu z uwagi na brak odpowiednich umiejętności

\subsection{Spoleczeństwo informacyjne w Polsce w ujęciu syntetycznym}

Jednym z mierników funkcjonujących obecnie w zakresie rozwoju społeczeństwa informacyjnego i technologii informacyjno-komunikacyjnych na świecie jest wskazany wcześniej ICT Development Index.

Najnowszy ranking wybranych krajów świata według tego indeksu przedstawia raport ITU - Measuring the Information Society 2012. W tej, już czwartej, edycji badania uwzględniono 155 państw. Zestawienie podstawowych charakterystyk ICT Development Index i jego trzech mierników cząstkowych przedstawiono poniżej ${ }^{21}$.

Tabela 4. Podstawowe parametry statystyczne ICT Development Index i mierników cząstkowych dla grupy 155 państw

\begin{tabular}{|l|c|c|c|c|}
\hline \multicolumn{1}{|c|}{ Miernik } & $\begin{array}{c}\text { Średnia } \\
\text { arytmetyczna }\end{array}$ & $\begin{array}{c}\text { Odchylenie } \\
\text { standardowe }\end{array}$ & $\begin{array}{c}\text { Wartość } \\
\text { minimalna }\end{array}$ & $\begin{array}{c}\text { Wartość } \\
\text { maksymalna }\end{array}$ \\
\hline ICT Development Index & 4,15 & 2,13 & 0,88 & 8,56 \\
\hline miernik cząstkowy „dostęp” & 4,66 & 2,29 & 0,85 & 9,21 \\
\hline $\begin{array}{l}\text { miernik cząstkowy „wykorzy- } \\
\text { stanie” }\end{array}$ & 2,47 & 2,21 & 0,04 & 8,17 \\
\hline $\begin{array}{l}\text { miernik cząstkowy „umiejętno- } \\
\text { ści” }\end{array}$ & 6,51 & 2,13 & 1,45 & 9,86 \\
\hline
\end{tabular}

Źródło: opracowanie na podstawie Measuring the Information Society 2012, International Telecommunication Union, Geneva 2012, s. 19-21.

${ }^{21}$ Wszystkie mierniki (główny i cząstkowy) przyjmują wartości z przedziału od 0 do 10 . Ogólną strukturę ICT Development Index (mierniki cząstkowe, ich wagi oraz łączną liczbę zmiennych wchodzących w jego skład) wskazano we wcześniejszym podrozdziale. 
Jak wynika $\mathrm{z}$ najnowszego raportu ITU, średnia wartość miernika ICT Development Index dla 155 państw z całego świata wyniosła w tej edycji 4,15, a średnie wartości mierników cząstkowych różniły się między sobą znacznie. Współczynnik zmienności $V_{s}$ dla ICT Development Index (liczony dla średniej i odchylenia standardowego z tabeli 4) kształtował się na poziomie 51,33\%. Badane $\mathrm{w}$ tym roku kraje były więc bardzo zróżnicowane pod względem wartości głównego indeksu. Co więcej, znaczne zróżnicowania międzynarodowe miały miejsce także w przypadku poszczególnych mierników cząstkowych. $V_{s}$ wyniósł dla nich odpowiednio: 49,1\% (miernik cząstkowy „dostęp"), 89,5\% (,wykorzystanie”) oraz 32,7\% ( ,umiejętności”).

W rankingu 155 państw znalazła się również Polska. W najnowszym zestawieniu osiągnęła ona wartość ICT Development Index na poziomie 6,19 (Tabela 5), zajmując tym samym 31 lokatę w grupie 155 państw. Nie jest to słaby wynik, gdyż Polska wyprzedziła w rankingu aż 124 kraje. Poza tym wartość ICT Development Index była w jej przypadku wyraźnie wyższa od średniej dla wszystkich badanych państw.

Tabela 5. Wartości miernika ICT Development Index i mierników cząstkowych

\begin{tabular}{|l|c|c|c|}
\hline \multirow{2}{*}{ Miernik } & \multicolumn{2}{|c|}{ Polska } & Świat (155 państw) \\
\cline { 2 - 4 } & $\begin{array}{c}\text { wartość } \\
\text { miernika }\end{array}$ & $\begin{array}{c}\text { lokata } \\
\text { w rankingu }\end{array}$ & $\begin{array}{c}\text { wartość } \\
\text { średnia }\end{array}$ \\
\hline ICT Development Index & 6,19 & 31 & 4,15 \\
\hline Miernik cząstkowy „dostęp” & 6,46 & 43 & 4,66 \\
\hline Miernik cząstkowy „wykorzystanie” & 4,57 & 32 & 2,47 \\
\hline Miernik cząstkowy „umiejętności” & 8,89 & 17 & 6,51 \\
\hline
\end{tabular}

Źródło: jak do tabeli 4, s. 19-21, 38-46.

Biorąc pod uwagę poszczególne mierniki cząstkowe wchodzące w skład ICT Development Index, pozycja Polski również nie jest najgorsza, ale z pewnością daleko jej do czołówki. Każdy z mierników cząstkowych osiągnął wartość wyższą od średniej dla 155 państw, a szczególnie wysoka była ona w przypadku miernika „umiejętności”, dając Polsce 17 lokatę w rankingu.

Wśród pierwszych trzydziestu państw o najwyższej wartości ICT Development Index oprócz krajów azjatyckich, Australii, czy Stanów Zjednoczonych, znalazło się również liczne grono krajów europejskich. Polskę wyprzedziło $\mathrm{w}$ tym rankingu aż dziewiętnaście, z czego szesnaście należących do Unii Europejskiej. Szczególnie wysoko w rankingu (tuż za Koreą) znalazły się zwłaszcza Szwecja (2. lokata), Dania (3.), Finlandia (5.), Holandia (6.) oraz Luksemburg (7.). W porównaniu z innymi krajami Unii Europejskiej Polska nie wypada więc pod tym względem dobrze, a niższe wartości ICT Development Index otrzymały jedynie Portugalia i Grecja oraz większość państw, które od 
2004 roku przystąpiły do Unii Europejskiej (wyjątek stanowią Malta, Słowenia i Estonia, które znalazły się w pierwszej „trzydziestce” zestawienia).

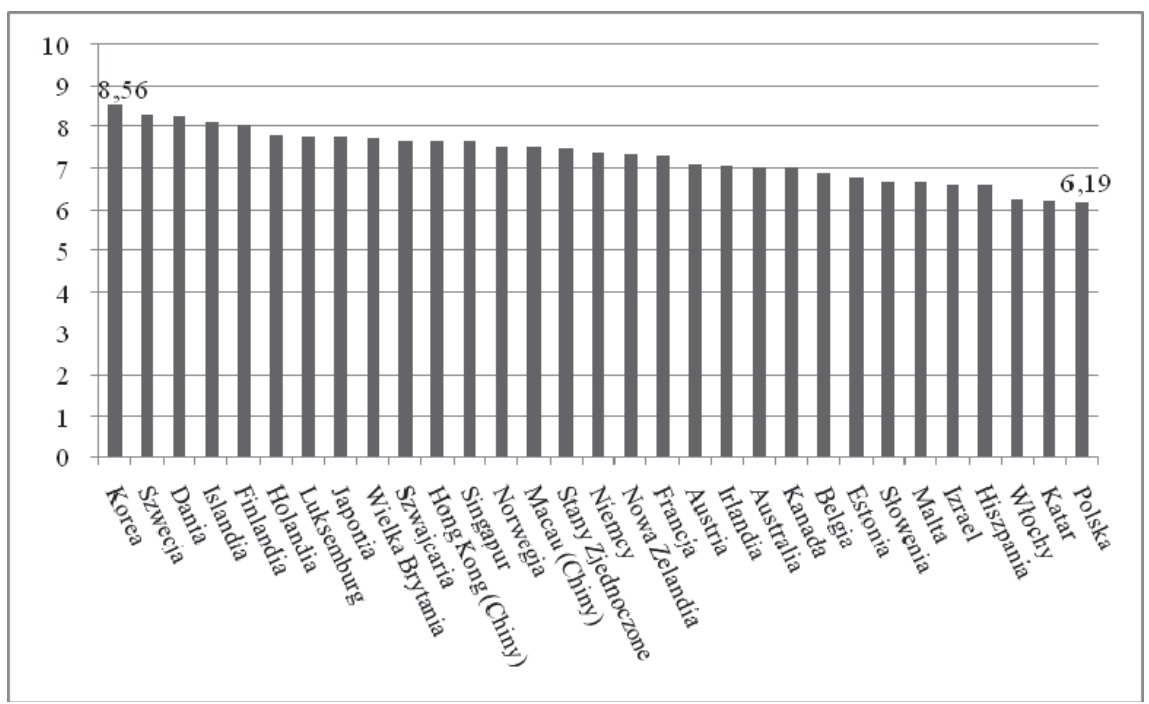

Rysunek 6. Państwa o najwyższej wartości miernika ICT Development Index

Źródło: opracowanie własne na podstawie: Measuring the Information Society 2012, International Telecommunication Union, Geneva, s. 21.

\section{Zakończenie}

Dynamiczny rozwój technologii informacyjno-komunikacyjnych i pojawiające się nieustannie ich nowe zastosowania nieuchronnie prowadzą w kierunku „społeczeństwa informacyjnego". Przekształcenia te następują jednak w poszczególnych krajach w różnym tempie, w konsekwencji czego mogą się one różnić stopniem rozwoju społeczeństwa informacyjnego. Pomiar stopnia rozwoju tego społeczeństwa nie jest jednak zadaniem prostym. Mimo to, zachodzące współcześnie procesy i zjawiska wymuszają jego wymierną identyfikację. Polska, jak wskazują wybrane wskaźniki, z pewnością nie należy do czołówki państw w zakresie rozwoju społeczeństwa informacyjnego. Wśród krajów Unii Europejskiej z reguły zajmuje ona odległe pozycje, choć nieco lepiej wygląda jej ogólna sytuacja w skali świata w zakresie rozwoju ICT. Polska w najnowszym raporcie International Telecommunication Union znalazła się bowiem na 31. miejscu w rankingu 155 państw pod względem wartości indeksu ICT Development Index, wyprzedzając tym samym dziesięć państw spośród wszystkich 27 krajów członkowskich Unii Europejskiej. 


\section{Literatura}

Goban-Klas T., Sienkiewicz P., Społeczeństwo informacyjne: szanse, zagrożenia, wyzwania, Wyd. Fundacji Postępu Telekomunikacji, Kraków 1999.

Goliński M., Społeczeństwo informacyjne - geneza koncepcji i problematyka pomiaru, Wyd. SGH, Warszawa 2011.

Konopka M., Istota i rozwój społeczeństwa informacyjnego, [w:] M. Witkowska, K. CholawoSosnowska (red.), Spoleczeństwo inform@cyjne. Istota, rozwój, wyzwania, Wyd. Akademickie i Profesjonalne, Warszawa 2006.

Kupczyk R., Gospodarczo-polityczne uwarunkowania rozwoju społeczeństwa informacyjnego,

Wyd. Akademii Polonijnej „Educator”, Częstochowa 2006.

Luterek M., E-government. Systemy informacji publicznej, Wyd. Akademickie i Profesjonalne, Warszawa 2010.

Luterek M., Mierzalność spoleczeństwa informacyjnego za pomoca wskaźników prostych, http://www.bbc.uw.edu.pl/Content/20/10.pdf.

Measuring the Information Society 2012, International Telecommunication Union, Geneva, 2012.

Moore N., The information society, World Information Report 1997/1998, UNESCO, Paris 1997.

Nowak J.S., Spoleczeństwo informacyjne - geneza i definicje, [w:] P. Sienkiewicz, J.S. Nowak (red.), Spoleczeństwo informacyjne. Krok naprzód, dwa kroki wstecz, Polskie Towarzystwo Informatyczne - Oddział Górnośląski, Katowice 2008.

Projekt ESPON 1.2.3 Identyfikacja istotnych przestrzennie aspektów społeczeństwa informacyjnego, Raport końcowy 2007.

Społeczeństwo informacyjne $w$ Polsce. Wyniki badań statystycznych z lat 2004-2008, GUS, Warszawa 2010.

Strategia e-rozwoju województwa mazowieckiego na lata 2007-2013, Tarnów-Warszawa $2005 / 2006$.

Strategia rozwoju spoleczeństwa informacyjnego w Polsce do roku 2013, Ministerstwo Spraw Wewnętrznych i Administracji, Warszawa 2008.

The Global Information Technology Report 2013. Growth and Jobs in a Hyperconnected World, World Economic Forum and INSEAD, Geneva 2013.

http://epp.eurostat.ec.europa.eu/portal/page/portal/information_society/data/database http://epp.eurostat.ec.europa.eu/.

http://www.itu.int.

http://www.weforum.org/.

\section{Streszczenie}

Druga połowa XX. i początek XXI stulecia to okres znaczących przemian związanych $\mathrm{z}$ rozwojem technologii ICT i powstawaniem społeczeństwa informacyjnego. W artykule przedstawiono pojęcie społeczeństwa informacyjnego i jego cechy charakterystyczne, jak również problem pomiaru stopnia rozwoju tego społeczeństwa i wybrane jego mierniki. Następnie dokonano oceny pozycji Polski pod względem rozwoju społeczeństwa informacyjnego w skali Europy i świata oraz zmian, jakie nastąpiły w tym zakresie w ostatnich latach. 


\section{Summary \\ INFORMATION SOCIETY - THE NOTION, MEASUREMENT AND THE LEVEL OF DEVELOPMENT IN POLAND}

The second half of the $20^{\text {th }}$ century and the beginning of the $21^{\text {st }}$ century it is a period of significant changes related to the ICT development and the emergence of the information society. This paper presents the notion of the information society and its characteristics, as well as the problem of measuring the level of information society' development and its selected indexes. The next part of the paper covers the analysis of the Polish position in Europe and in the world in terms of the information society' development and changes that have occurred in this area in recent years. 